\title{
A comparative study of serum electrolytes in newborns with birth asphyxia and non-asphyxiated newborns
}

\author{
Manjunatha Babu R , Pavan Kumar Jerry², Harish $\mathbf{G}^{3}$, Susheela $\mathbf{C}^{4}$. \\ ${ }^{1}$ Dr. Manjunatha Babu R, Associate Professor, Department of Paediatrics, ${ }^{2}$ Dr. Pavan Kumar Jerry, Assistant Professor, \\ Department of Paediatrics, ${ }^{3}$ Dr. Harish G, Associate Professor, Department of Paediatrics, ${ }^{4}$ Dr. Susheela C, Professor \& \\ HOD, Department of Paediatrics; All authors are affiliated with Vydehi Institute Medical Sciences and Research Centre, \\ Bengaluru, Karnataka, India.
}

Corresponding Author: Dr. Pavan Kumar Jerry, Assistant Professor, Department of Paediatrics, Vydehi Institute of Medical Sciences and Research Centre, White field, Bengaluru. Email id: jerrypavan8477@gmail.com

\begin{abstract}
Background: Birth asphyxia is a common neonatal problem and contributes significantly to neonatal morbidity and mortality. HIE is the foremost concern in asphyxiated neonate because contrary to other system derangements this has the potential to cause serious long term neuromotor sequel among survivors. Sodium, potassium and calcium are the major electrolytes in human body, and any deviation from their normal levels in blood might cause convulsions, shock and other metabolic abnormalities. Immediate aggressive treatment of these abnormalities could modify the entire outcome of the babies. Methods: The study was a case control study conducted over a period of 2 years. Case (asphyxiated) group comprised of term babies weighing $2.5 \mathrm{~kg}$ or more with birth asphyxia. Birth asphyxia was said to be present in those babies who had a definite APGAR score of less than 7 at 1 minute of birth. Control (non-asphyxiated) group was made up of term babies weighing $2.5 \mathrm{~kg}$ or more with APGAR scores of 7 or more at 1 minute of birth. Blood samples collected were immediately sent to the biochemistry lab for evaluation of serum sodium, potassium and calcium. Results: A total of 100 newborn babies were included in the study, 50 babies in case group and 50 babies in control group. Mean serum sodium and calcium values were significantly lower in the asphyxiated group when compared to the non-asphyxiated group. Mean serum potassium was significantly higher in the asphyxiated group when compared to the non-asphyxiated group. The mean serum sodium and calcium values in severely asphyxiated babies were significantly lower when compared to mild/moderately asphyxiated babies and the non-asphyxiated group. Conclusions: As serum sodium levels are low in birth asphyxia, fluids must be managed judiciously in asphyxiated newborns.
\end{abstract}

Key words: Asphyxia, Calcium, Potassium, Sodium

\section{Introduction}

Birth asphyxia is a common neonatal problem and contributes significantly to neonatal morbidity and mortality[1]. The signs of asphyxial injury are nonspecific and overlap with other illnesses. In the absence of perinatal records, it is difficult to retrospectively diagnose perinatal asphyxia. Perinatal asphyxia may result in adverse effects on all major body systems. In a term infant with perinatal asphyxia renal, neurologic, and cardiac and lung dysfunction occurs in $50 \%, 28 \%, 25 \%$ and $23 \%$ cases respectively [2]. HIE is the foremost concern in asphyxiated neonate because contrary to other system derangements this has the potential to cause serious long term neuromotor sequel

Manuscript received: $8^{\text {th }}$ August 2018

Reviewed: $20^{\text {th }}$ August 2018

Author Corrected: $27^{\text {th }}$ August 2018

Accepted for Publication: $31^{\text {st }}$ August 2018 among survivors. Despite the increasing understanding of the mechanisms leading to and resulting from neonatal asphyxia, early determination of brain damage following hypoxic-ischemic events still remains the hardest problems in neonatal care $[3,4,5]$. Brief hypoxia impairs cerebral oxidative metabolism leading to an anaerobic glycolysis to generate ATP.

Anaerobic metabolism ensues with production of large quantities of metabolic degradation products like lactic acid $[6,7,8,9,10]$. During prolonged hypoxia, cardiac output falls, cerebral blood flow is compromised and a combined hypoxic-ischemic insult produces further failure of oxidative phosphorylation and ATP production, sufficient to cause cellular damage. Due to cellular damage the levels of serum potassium increase, 
consequently the levels of sodium reduce due to increase secretion of $\mathrm{ADH}$ and water retention and hypoxic injury to the renal tubules. Serum levels of calcium also tend to drop due to hypoxic ischemic damage to the parathyroid glands $[6,7,8,9,10]$. Sodium, potassium and calcium are the major electrolytes in human body, and any deviation from their normal levels in blood might cause convulsions, shock and other metabolic abnormalities.

Calcium is an important second messenger in our body and also helps carrying out muscle function and acts as cofactor for several enzymatic activities. Knowledge of these abnormalities to the clinician is very valuable as it is an important variable affecting perinatal mortality. Immediate aggressive treatment of these abnormalities could modify the entire outcome of the babies. Though there are more and more studies for understanding mechanisms leading to birth asphyxia, studies for early determination of tissue damages due to birth asphyxia are still lacking.

\section{Methodology}

The study is a case control study conducted at the Neonatal Intensive Care Unit Vydehi medical college hospital Bangalore over a period of 2 years. Case (asphyxiated) group comprised of term babies weighing $2.5 \mathrm{~kg}$ or more with birth asphyxia. Birth asphyxia was said to be present in those babies who had a definite APGAR score of less than 7 at 1 minute of birth. Severity of Birth Asphyxia was further classified as mild/moderate or severe depending on the APGAR Score at 1 minute as follows: Mild/Moderate birth asphyxia: APGAR Score 4-6, Severe birth asphyxia: APGAR Score 0-3. Control (non-asphyxiated) group was made up of term babies weighing $2.5 \mathrm{~kg}$ or more with APGAR scores of 7 or more at 1 minute of birth.

The babies admitted to the NICU for observation and not having birth asphyxia or any of the exclusion criteria were included in the non-asphyxiated group. Babies in the non-asphyxiated group were matched to the asphyxiated group based on the mode of delivery. A written informed consent of parents was taken before inclusion of the newborns into the study. All the neonates included in the study were subjected to detailed maternal history, thorough clinical examination, recording of APGAR score at 1 minute \& 5 minutes, assessment of staging of HIE by Sarnat and Sarnat Staging and collection of blood sample using aseptic precautions for serum electrolytes $(\mathrm{Na}, \mathrm{K} \& \mathrm{Ca})$ of newborn baby immediately after birth and the details were recorded in the pre-structured proforma.

Inclusion criteria: 1) Asphyxiated group - Term babies weighing $2.5 \mathrm{~kg}$ or more with APGAR scores of $<7$ at $1 \mathrm{~min}, 2)$ Non-asphyxiated group- Term babies weighing $2.5 \mathrm{~kg}$ or more with APGAR scores of $\geq 7$ at 1 minute of birth. Exclusion criteria: Suspected metabolic disease, Babies treated with diuretics, Babies born to mothers receiving drugs likely to cause CNS depression or dyselectrolytemia in babies. The gestational age was determined by using new Ballard's score. The birth weight was measured by electronic weighing machine.

Blood samples collected were immediately sent to the biochemistry lab for evaluation of serum sodium, potassium and calcium. Serum sodium, potassium were estimated by ion selective electrode method analyzed by a radiometer. Serum calcium was estimated by Arsenazo III method using a BS380 auto-analyzer. The serum electrolyte values in the asphyxiated and nonasphyxiated groups were compared in order to evaluate whether there was any difference in serum sodium, potassium and calcium levels.Serum sodium, potassium and calcium values were compared between mild/moderate and severely asphyxiated groups, to determine if there was any variation in their values based on the severity of asphyxia.

Statistical Methods- Descriptive and inferential statistical analysis has been carried out in the present study. Analysis of variance (ANOVA) has been used to find the significance of study parameters between three or more groups of patients. Chi-square/Fisher Exact test has been used to find the significance of study parameters on categorical scale between two or more groups.

\section{Results}

Total number of 3269 deliveries conducted during the study period, 736 newborns babies were admitted to NICU. A total of 100 newborn babies were included in the study, 50 babies in case group and 50 babies in control group. Among the asphyxiated group $66 \%$ were born by cesarean section and $34 \%$ by vaginal delivery and this was matched with the nonasphyxiated group. In the asphyxiated group, 58\% were males and $42 \%$ were females whereas in the non-asphyxiated group $60 \%$ were males and $40 \%$ were females. Among the 50 neonates in the asphyxiated group, 33 babies had mild/moderate asphyxia out of which $54.5 \%$ were males and $45.5 \%$ were females, whereas 17 babies had severe asphyxia of which $64.7 \%$ were males and $35.3 \%$ were females. In our study most of the babies in both the asphyxiated and non- 
asphyxiated groups had a gestational age of 38 weeks followed by 37 weeks. Among the 50 neonates in the asphyxiated group, $62 \%$ were born to primi para mothers and $38 \%$ were born to multi para mothers. Among the non-asphyxiated group of 50 neonates, $56 \%$ were born to primi para mothers and $44 \%$ were born to multi para mothers [Table.1].

Table-1: Characteristics of study newborns.

\begin{tabular}{|c|c|c|c|c|c|}
\hline \multicolumn{2}{|c|}{ Character } & \multirow{2}{*}{$\begin{array}{c}\begin{array}{c}\text { Asphyxiated } \\
\text { group } \\
\text { n (\%) }\end{array} \\
33(66 \%)\end{array}$} & \multirow{2}{*}{$\begin{array}{c}\begin{array}{c}\text { Non-asphyxiated } \\
\text { group } \\
\text { n (\%) }\end{array} \\
33(66 \%)\end{array}$} & \multirow{2}{*}{$\begin{array}{c}\text { Total } \\
\text { n (\%) } \\
66(66 \%)\end{array}$} & \multirow{3}{*}{$\begin{array}{c}\text { “p” Value } \\
0.98\end{array}$} \\
\hline Mode of & LSCS & & & & \\
\hline Delivery & Vaginal Delivery & $17(34 \%)$ & $17(34 \%)$ & $34(34 \%)$ & \\
\hline \multirow[b]{2}{*}{ Sex } & Male & $29(58 \%)$ & $30(60 \%)$ & $59(59 \%)$ & \multirow[b]{2}{*}{0.84} \\
\hline & Female & $21(42 \%)$ & $20(40 \%)$ & $41(41 \%)$ & \\
\hline \multirow{5}{*}{$\begin{array}{c}\text { Gestational } \\
\text { Age }\end{array}$} & 37 Weeks & $16(32 \%)$ & $13(26 \%)$ & $29(29 \%)$ & \multirow{5}{*}{0.42} \\
\hline & 38 Weeks & $22(44 \%)$ & $20(40 \%)$ & $42(42 \%)$ & \\
\hline & 39 Weeks & $7(14 \%)$ & $11(22 \%)$ & $18(18 \%)$ & \\
\hline & 40 Weeks & $4(8 \%)$ & $5(10 \%)$ & $9(9 \%)$ & \\
\hline & 41 Weeks & $1(2 \%)$ & $1(2 \%)$ & $2(2 \%)$ & \\
\hline \multirow{2}{*}{$\begin{array}{c}\text { Parity of } \\
\text { the Mother }\end{array}$} & Primi para & $31(62 \%)$ & $28(56 \%)$ & $59(59 \%)$ & \multirow[b]{2}{*}{0.54} \\
\hline & Multipara & $19(38 \%)$ & $22(44 \%)$ & $41(41 \%)$ & \\
\hline
\end{tabular}

In our study $94 \%$ of the asphyxiated group had hyponatremia (serum sodium $<135 \mathrm{mmol} / \mathrm{l}$ ) whereas only $8 \%$ of the nonasphyxiated group had hyponatremia and this difference was observed to be statistically significant. In our study $32 \%$ of the asphyxiated group had hyperkalemia (serum potassium $>5.5 \mathrm{mmol} / \mathrm{l}$ ) whereas $14 \%$ of the non-asphyxiated group had hyperkalemia and this difference was observed to be statistically significant. In our study, the asphyxiated group had $96 \%$ of babies had Serum Calcium $\geq 7 \mathrm{mg} / \mathrm{dl}$ and only $4 \%$ had hypocalcaemia whereas all the babies in the non-asphyxiated group had Serum Calcium $\geq 7 \mathrm{mg} / \mathrm{dl}$ [Fig.1]. It was observed that the difference was not statistically significant (p-value $>$ 0.05). Mean serum sodium and calcium values were significantly lower in the asphyxiated group when compared to the non-asphyxiated group. Mean serum potassium was significantly higher in the asphyxiated group when compared to the non-asphyxiated group [Table2].

Table-2: Serum electrolytes status in the asphyxiated and non-asphyxiated groups.

\begin{tabular}{|c|c|c|c|}
\hline Serum Electrolytes & $\begin{array}{c}\text { Asphyxiated group } \\
\mathbf{n}=\mathbf{5 0} \\
\mathbf{( M E A N} \pm \text { SD) }\end{array}$ & $\begin{array}{c}\text { Non-asphyxiated group } \\
\mathbf{n = 5 0} \\
\text { (MEAN } \pm \text { SD) }\end{array}$ & p-value \\
\hline Sodium (mmol /L) & $128.96 \pm 3.9$ & $139.58 \pm 3.78$ & $<0.001$ \\
\hline Potassium (mmol/L) & $5.32 \pm 0.57$ & $4.92 \pm 0.49$ & $<0.001$ \\
\hline Calcium (mg/d) & $7.95 \pm 0.56$ & $8.80 \pm 0.63$ & $<0.001$ \\
\hline
\end{tabular}

The mean serum sodium and calcium values in severely asphyxiated babies were significantly lower when compared to mild/moderately asphyxiated babies and the non-asphyxiated group. It was also observed that the mean serum sodium and calcium levels were significantly lower in mild/ moderately asphyxiated babies when compared to the nonasphyxiated group.

The mean serum potassium value in severely asphyxiated babies when compared to mild/moderately asphyxiated babies was only marginally raised, which was not statistically significant. It was also observed that the mean serum potassium level was significantly high in mild/ moderately and severely asphyxiated babies, when compared to the non-asphyxiated group, which was statistically significant [Table.3]. 
Original Research Article

Table-3: Serum electrolytes status in asphyxiated newborns of varying severity and non-asphyxiated groups

\begin{tabular}{|c|c|c|c|c|}
\hline Serum Electrolytes & $\begin{array}{c}\text { Severe Birth } \\
\text { Asphyxia } \\
\mathbf{n = 1 7} \\
\text { (MEAN } \pm \text { SD) }\end{array}$ & $\begin{array}{c}\text { Mild/Moderate } \\
\text { Birth Asphyxia } \\
\text { (MEAN } \pm \text { SD) }\end{array}$ & $\begin{array}{c}\text { Non-asphyxiated } \\
\text { groups } \\
\mathbf{n}=\mathbf{5 0} \\
\text { (MEAN } \pm \text { SD) }\end{array}$ & P- values \\
\hline $\begin{array}{c}\text { Sodium } \\
\text { (mmol /L) }\end{array}$ & $127.18 \pm 4.864$ & $129.88 \pm 3.140$ & $139.58 \pm 3.786$ & 0.019 \\
& & & & $<0.001$ \\
\hline Potassium (mmol/L) & $5.28 \pm 0.722$ & $5.34 \pm 0.494$ & $4.92 \pm 0.499$ & 0.711 \\
& & & & 0.020 \\
\hline Calcium (mg/d) & $7.69 \pm 0.488$ & $8.08 \pm 0.565$ & $8.80 \pm 0.635$ & 0.001 \\
\hline
\end{tabular}

\section{Distribution of cases with electrolytes levels}

Serum sodium $\geq 135 \mathrm{mmol} / \mathrm{L}$

Serum sodium $<135 \mathrm{mmol} / \mathrm{L}$

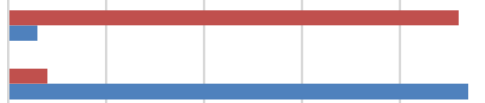

Odds Ratio: 180.17 ( 95\%C.I

38.19-849.86). p: $<0.001$

Serum Potassium $\leq 5.5 \mathrm{mmol} / \mathrm{L}$

Serum Potassium $>5.5 \mathrm{mmol} / \mathrm{L}$

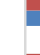

$$
\text { S }
$$$$
\begin{aligned}
& \text { Serum Calcium } \geq 7 \mathrm{mg} / \mathrm{dl} \\
& \text { Serum Calcium }<7 \mathrm{mg} / \mathrm{dl}
\end{aligned}
$$$$
0
$$

Non-asphyxiated group $\square$ Asphyxiated group

Fig-1

\section{Discussion}

This study conducted on asphyxiated and nonasphyxiated newborns, compared the pattern of electrolyte disturbances in them. It also correlated the serum electrolyte pattern with severity of birth asphyxia based on APGAR score.

In our study the incidence of asphyxia was higher in the male babies and constituted $58 \%$ of total asphyxiated cases which is comparable to the study done by Pallab Basu et al where the male babies constituted $64 \%$ of the total asphyxiated cases [11]. It was observed that the mean birth weight in the asphyxiated group was

$2.74 \pm 0.36$ and non-asphyxiated group was $2.78 \pm 0.33$, which is almost similar to the study done by Pallab Basu et al [11]. The serum electrolyte values in the asphyxiated and non-asphyxiated groups were compared in order to evaluate

whether there was any difference in their levels. In the present study, mean serum sodium level in the asphyxiated neonates was $128.96 \pm 3.9 \mathrm{mmol} / \mathrm{L}$, which was significantly lower in comparison to the nonasphyxiated neonates, who had a value of $139.58 \pm 3.7$ $\mathrm{mmol} / \mathrm{L}(\mathrm{p}<0.001)$. The results of the present study 
were in concordance with those of Pallab Basu et al [11]. They reported that the mean serum sodium level was $122.1 \pm 6.0 \mathrm{mmol} / \mathrm{L}$, which was significantly lower compared to the non-asphyxiated neonates, who had a value of $138.8 \pm 2.7 \mathrm{mmol} / \mathrm{L}(\mathrm{p}<0.001)$. We noticed that serum sodium levels were decreasing with the increasing severity of asphyxia showing a significant positive correlation with a $\mathrm{r}$ value of 0.808 and a $\mathrm{p}$ value $<0.001$. Pallab Basu et al also found a significant positive correlation between serum levels of sodium and APGA Rscore [11].

Low serum sodium levels in birth asphyxia may be due to dilutional hyponatremia caused byinappropriate secretion of anti diuretic hormone. The mean serum potassium level in the asphyxiated group was $5.32 \pm 0.57$ $\mathrm{mmol} / \mathrm{L}$, which was significantly higher when compared to the non-asphyxiated group which had a value of $4.92 \pm 0.49 \mathrm{mmol} / \mathrm{L}(\mathrm{p}<0.001)$.

The mean serum potassium level in the asphyxiated group was within the upper limit of the normal range. Pallab Basu et al found out that mean serum potassium level inthe asphyxiated group was $5.05 \pm 0.63 \mathrm{mmol} / \mathrm{L}$, which was slightly higher as compared to the nonasphyxiated group, which had a value of $4.19 \pm 0.40$ $\mathrm{mmol} / \mathrm{L} .(\mathrm{p}<0.001)$, but the levels were found to be within the normal range[11].

In this study serum potassium levels were increasing with the increasing severity of asphyxia showing a negative correlation with a $r$ value of -0.325 and a $p$ value $<0.001$. Pallab Basu et al also also found a significant negative correlation between serum levels of potassium and APGAR score [11].

Higher serum potassium levels in birth asphyxia may be due to acute renal failure or hypoxic cell injury leading to release of potassium into the extracellular fluid. The mean serum calcium level in the asphyxiated group was $7.95 \pm 0.56 \mathrm{mg} / \mathrm{dl}$, which was significantly lower in comparison to the non-asphyxiated group which had a value of $8.80 \pm 6.3 \mathrm{mg} / \mathrm{dl},(\mathrm{p}<0.001)$ but the levels were found to be within the normal range.

In the PallabBasu et al study, the mean serum calcium level in the asphyxiated group was $6.85 \pm 0.95 \mathrm{mg} / \mathrm{dl}$ and was significantly lower when compared to the nonasphyxiated group, which had a value of $9.50 \pm 0.51$ $\mathrm{mg} / \mathrm{dl} ; \quad(\mathrm{p}<0.001)[11]$. In the present study serum calcium levels were decreasing with the increasing severity of asphyxia showing a positive correlation with a $r$ value of 0.549 and a $p$-value $<0.001$. PallabBasu et alalso found a significant positive correlation between serum levels of calcium and APGAR score [11]. Another study was done by Alphonsus N. Onyiriuka on serum calcium levels in asphyxiated term newborns, however it is not comparable with our study as they have studied serum calcium levels at 12,24 and 48 hours after birth [12]. Study done by Deepak Jajoo et alobserved that serum calcium levels were significantly lower in term appropriate for gestational age asphyxiated newborns [13]. They were of the opinion that hypoxia impairs the functions of parathyroid gland resulting in lower calcium levels. However, their sample size was smaller in comparison to our study \& PallabBasu et al's study and they have also included pre-term neonates in their study.

\section{Conclusion}

Serum sodium levels in the asphyxiated newborns were in the hyponatremic range and in proportion to the severity of asphyxia. As serum sodium levels are low in birth asphyxia, fluids must be managed judiciously in asphyxiated newborns.

\section{Contribution details}

- Dr. Manjunatha Babu R- Study designing and Tabulation

- Dr. Pavan Kumar Jerry- Data collection \& Data entry

- Dr. Harish G - Statistical analysis

- Dr. Susheela C- Guidance and over all supervision.

Funding: Nil, Conflict of interest: None initiated, Perission from IRB: Yes

\section{References}

1. Lawn JE, Cousens S, Zupan J; et al. 4 million neonatal deaths: when? Where? Why? Lancet. 2005 Mar 5-11;365(9462):891-900. doi:10.1016/S0140-6736 (05) 71048-5.

2. Perlman JM, Tack ED, Martin T, et al. Acute systemic organ injury in term infants after asphyxia. Am J Dis Child. 1989 May;143(5):617-20.

3. Perlman JM. Markers of asphyxia and neonatal brain injury. N Engl J Med. 1999 Jul 29;341(5):364-5. doi:10. 1056/NEJM199907293410510.

4. Volpe JJ. Neurology of newborn, 3rd ed, W. B. Saunders Company, 1995:211-360.

5. Marlow N. Do we need an Apgar score? Arch Dis Child. 1992 Jul;67(7 Spec No):765-7. 
6. Porter KB, O'Brien WF, Benoit R. Comparison of cord purine metabolites to maternal and neonatal variables of hypoxia. Obstet Gynecol. 1992 Mar;79(3): 394-7.

7. Palmer C, Vannucci RC, Towfighi J. Reduction of perinatal hypoxic-ischemic brain damage with allopurinol. Pediatr Res. 1990 Apr; 27 (4 Pt 1): 332-6. doi: 10. 1203/00006450-199004000-00003.

8. Poulsen JP, Rognum TO, Oyasaeter S, Saugstad OD. Changes in oxypurine concentrations in vitreous humor of pigs during hypoxemia and post-mortem. Pediatr Res. 1990 Nov; 28 (5):482-4. doi:10.1203/00006450199011000-00013.

9. Swanström S, Bratteby LE. Hypoxanthine as a test of perinatal hypoxia as compared to lactate, base deficit, and pH.Pediatr Res. 1982 Feb;16(2):156-60.
10. Poulsen JP, Oyasaeter S, Sanderud J, et al. Hypoxanthine, xanthine, and uric acid concentrations in the cerebrospinal fluid, plasma, and urine of hypoxemic pigs. Pediatr Res. 1990 Nov;28(5):477-81. doi:10. 1203 / 00006450-199011000-00012.

11. Basu P, Som S, Das H, Choudhuri N. Electrolyte status in birth asphyxia. Indian J Pediatr. 2010 Mar; 77 (3) : 259-62. doi: 10.1007/s12098-010-0034-0. Epub 2010 Feb 22.

12. Onyiriuka A N. Prevalence Of Neonatal Hypocalcaemia Among Full-Term Infants With Severe Birth Asphyxia. PJMS; 2011 April; 8(1): 3-12.

13. Jajoo D, Kumar A, Shankar R, Bhargava V. Effect of birth asphyxia on serum calcium levels in neonates. Indian J Pediatr. 1995 Jul-Aug;62(4):455-9.

\section{How to cite this article?}

Manjunatha Babu R, Pavan Kumar Jerry, Harish G, Susheela C. A comparative study of serum electrolytes in newborns with birth asphyxia and non-asphyxiated newborns. Int J Pediatr Res.2018;5(8): 407-412.doi:10.17511/ijpr.2018.i08.04. 